\title{
PERSEPSI TENTANG RISIKO BREAKTHROUGH INFECTION COVID-19 DALAM LINGKUNGAN HEALTH RISK MESSAGES
}

\author{
Tandiyo Pradekso ${ }^{1 *}$, Djoko Setyabudi ${ }^{1}$ \\ ${ }^{1}$ Departemen Ilmu Komunikasi, FISIP, Universitas Diponegoro Semarang \\ *Email: tandiyopradekso@lecturer.undip.ac.id
}

\begin{abstract}
The Covid-19 vaccination rate continues to increase, it is important to pay attention to the possibility of a breakthrough infection, which is a viral infection that occurs after a person has been vaccinated. This is a case that is expected to occur in some of those who have received the vaccine, as no vaccine for any disease is 100 percent effective. During the time of living in this period of the Covid-19 pandemic, people are always exposed to information about the dangers or threats of exposure to the virus, known as health risk messages. This study was conducted to explain how a number of individual characteristics in the health risk message information environment correlate to their attitudes towards the risk of exposing Covid-19. This online survey of people who have received the Covid-19 vaccine found that several variables related to lifestyle and disease history were correlated to perceptions of the risk of exposure to Covid-19. It also confirms that there is a positive correlation between awareness of the amount of risk an individual has and perceptions of the risk of exposing Covid-19.
\end{abstract}

Keywords: Health Risk Messages; Breakthrough Infection; Covid-19

\begin{abstract}
ABSTRAK
Seiring dengan tingkat vaksinasi Covid-19 yang semakin tinggi, hal yang perlu diperhatikan adalah kemungkinan terjadinya breakthrough infection, yaitu infeksi virus yang terjadi setelah seseorang divaksinasi. Ini adalah kejadian yang diperkirakan dapat terjadi pada sebagian dari mereka yang telah menerima vaksin, karena tidak ada vaksin untuk penyakit apa pun yang 100 persen efektif. Pada saat yang sama, orang yang hidup dalam periode pandemi Covid-19 ini senantiasa mendapatkan terpaan informasi tentang bahaya atau ancaman dari keterpaparan terhadap virus tersebut. Informasi semacam ini dikenal sebagai health risk messages. Studi ini dilakukan untuk menjelaskan bagaimana sejumlah karakteristik individu di dalam lingkungan informasi health risk messages, berkorelasi dengan sikap mereka terhadap risiko tertular Covid-19. Survei secara daring terhadap orang yang telah mendapatkan vaksin Covid-19 ini menemukan bahwa beberapa variabel yang terkait dengan gaya hidup dan riwayat penyakit berkorelasi dengan persepsi tentang risiko terpapar Covid-19. Studi ini juga menegaskan adanya korelasi positif antara awareness pada jumlah risiko yang dimiliki oleh individu dengan persepsi tentang risiko tertular Covid-19.
\end{abstract}

Kata kunci: Health Risk Messages; Breakthrough Infection; Covid-19

Submisi: 14 Desember 2021

\section{Pendahuluan}

Situasi pandemi yang diakibatkan oleh merebaknya SARS Corona Virus 19 yang mulai muncul sejak akhir 2019 dan mulai melanda Indonesia pada awal tahun 2020, telah berangsur terkendali. Setelah mengalami sejumlah fluktuasi kasus paparan virus dengan puncaknya pada bulan Juli 2021, jumlah kasus paparan virus terus melandai. Data tentang kasus Covid-19 hingga minggu pertama bulan Desember 2021 menunjukkan penurunan yang konsisten. Juru bicara vaksinasi Covid-19 Kementerian Kesehatan RI, Siti Nadia Tarmizi mengemukakan bahwa angka kasus Covid-19 di Indonesia pada pekan pertama Desember 2021 turun hingga 200-300 kasus per hari dan angka positif terus turun dari 0,19 persen turun menjadi 0,17 persen dan sekarang menjadi 0,13 persen. Tingkat 
vaksinasi yang dilakukan kepada penduduk juga telah mencapai 76 persen untuk dosis pertama dan 56 persen untuk dosis kedua (Kompas, 8 Desember 2021). Kondisi keterpaparan Covid-19 yang landai dan rendah ini membuat Indonesia dianggap sebagai salah satu negara yang berhasil mengendalikan pandemi Covid-19 dengan baik hingga saat ini.

Meskipun demikian, prestasi ini tetap memerlukan sikap kewaspadaan yang tinggi karena pada saat yang bersamaan tengah terjadi lonjakan kasus yang tinggi di berbagai negara di Eropa, di Amerika Serikat, dan bahkan di negara tetangga Indonesia yaitu Singapura. Kekhawatiran akan terjadinya lonjakan kasus yang disebut gelombang ketiga muncul ketika warga masyarakat akan memasuki periode liburan akhir tahun 2021 yang meningkatkan mobilitas penduduk. Pada sisi yang lain mutasi virus Covid-19 terus terjadi dan menjadi semakin mudah menular. Saat ini jenis virus yang mendominasi kasus di Indonesia adalah varian Delta yang dianggap sangat mudah menular, sementara itu dalam beberapa pekan terakhir telah diidentifikasi munculnya varian Omicron di Afrika Selatan yang memiliki kecepatan penularan beberapa kali lipat dari varian Delta. Varian Omicron ini juga telah menyebar ke berbagai negara, meskipun hingga saat ini belum terdeteksi di Indonesia.

Satu hal lain yang perlu dicermati seiring dengan tingkat vaksinasi yang semakin tinggi adalah kemungkinan terjadinya breakthrough infection. Breakthrough infection adalah infeksi virus yang terjadi setelah seseorang divaksinasi. Ini adalah kejadian yang diperkirakan dapat terjadi pada sebagian dari mereka yang telah menerima vaksin, karena tidak ada vaksin untuk penyakit apa pun yang 100 persen efektif dalam mencegah infeksi pada setiap orang yang menerimanya. Kasus breakthrough COVID-19 dapat terjadi pada orang yang divaksinasi lengkap, dan tampaknya lebih sering terjadi sekarang karena varian Delta beredar luas dan kekebalan mungkin berkurang di antara mereka yang mendapat vaksin beberapa bulan yang lalu. Meskipun vaksin virus corona yang tersedia sangat baik untuk melindungi dari keparahan akibat COVID19, tetapi tetap tidak 100 persen efektif untuk mencegah terjadinya infeksi. Breakthrough COVID dapat disebabkan oleh varian Omicron, yang lebih menular daripada beberapa varian coronavirus lainnya. Lisa Maragakis dan Gabor Kelen, dari the Johns Hopkins Office of Critical Event Preparedness and Response, menjelaskan bahwa meskipun seseorang telah divaksinasi lengkap, dia dapat mengalami breakthrough infection. Orang dengan sistem imunitas yang lemah yang disebabkan oleh kondisi atau perawatan medis tertentu (termasuk transplantasi organ, HIV dan beberapa jenis kanker dan kemoterapi) lebih mungkin untuk mengalami breakthrough infection. CDC merekomendasikan agar orang atau pasien dengan sistem imunitas yang lemah menerima tambahan, atau dosis vaksin COVID-19 ketiga, pada 28 hari atau lebih setelah suntikan kedua mereka untuk memperkuat perlindungan mereka terhadap virus corona (hopkinsmedicine.org, 2021).

\begin{tabular}{llr}
\multicolumn{2}{c}{ Orang mulai mempertanyakan } \\
tentang & kemungkinan & breakthrough \\
infection & setelah mereka & mendapatkan \\
vaksinasi & Covid-19. Tara & Parker-Pope
\end{tabular} dalam artikelnya di New York Times (nytimes.com, 2021) mengemukakan bahwa banyak orang mencari informasi tentang apa yang bisa dan tidak bisa mereka lakukan setelah divaksinasi Covid-19. Apakah baikbaik saja untuk bepergian? Hadir ke pesta pernikahan? Apakah varian Delta membuat interaksi dengan keluarga yang telah divaksinasi tetap berisiko? Jika seseorang telah divaksinasi, maka dia harus memikirkan sejumlah variabel yang dapat mempengaruhi kerentanan untuk terjadinya breakthrough infection, termasuk faktor kesehatan secara keseluruhan, lingkungan tempat tinggal, dan risiko yang biasanya harus diambil. Tetapi tidak ada satu jawaban yang cocok untuk semua pertanyaan 
tersebut karena risiko berubah dari satu individu ke individu lainnya, tergantung pada kesehatan seseorang secara keseluruhan, di mana mereka tinggal dan dengan siapa mereka menghabiskan waktu. Intinya adalah bahwa vaksin sangat protektif terhadap penyakit serius, dan, dengan beberapa tindakan pencegahan, akan memungkinkan orang untuk kembali ke kehidupan yang lebih normal, kata para ahli. Sebuah penelitian baru-baru ini di Los Angeles County menunjukkan bahwa sementara breakthrough infection dapat terjadi, orang yang tidak divaksinasi $29 \mathrm{kali}$ lebih mungkin untuk dirawat di rumah sakit karena Covid-19 daripada orang yang divaksinasi.

Lebih lanjut, hasil penelitian yang dilakukan mulai 1 Mei 2021 hingga 25 Juli 2021 terhadap 10,895 kasus Covid-19 pada orang yang telah divaksinasi secara penuh dan 30,801 kasus pada orang yang belum divaksinasi tersebut menemukan bahwa tingkat infeksi pada orang yang tidak divaksinasi adalah lima kali tingkat infeksi pada orang yang divaksinasi. Pada akhir periode penelitian, insiden Covid-19 di antara orang yang tidak divaksinasi adalah 315,1 per 100.000 orang selama periode tujuh hari dibandingkan dengan tingkat kejadian 63,8 per 100.000 di antara orang yang divaksinasi penuh. Tingkat rawat inap di antara yang divaksinasi adalah 1 per 100.000 orang. Tingkat rawat inap pada orang yang tidak divaksinasi adalah 29,4 per 100.000. Orang yang lebih tua yang divaksinasi paling rentan terhadap keparahan setelah breakthrough infection. Usia rata-rata orang yang divaksinasi yang dirawat di rumah sakit karena Covid adalah 64 tahun. Di antara orang-orang yang tidak divaksinasi yang dirawat di rumah sakit, usia rata-ratanya adalah 49 tahun. Varian Delta juga telah meningkatkan risiko breakthrough infection pada orang yang divaksinasi. Pada awal penelitian, sebelum Delta dominan, orang yang tidak divaksinasi menjadi terinfeksi 10 kali lebih sering daripada orang yang divaksinasi. Pada akhir masa studi, ketika Delta menyumbang hampir 90 persen infeksi, orang yang tidak divaksinasi 5 kali lebih mungkin terinfeksi daripada orang yang divaksinasi.

Ada beberapa faktor yang dapat meningkatkan risiko seseorang terkena breakthrough infection. Alasan utamanya adalah munculnya varian-varian baru. Delta dan Omicron misalnya, dikatakan sangat menular dan mungkin dapat menghindari kekebalan yang diinduksi vaksin. Mengingat bahwa vaksin COVID dikembangkan dari jenis COVID asli/awal, varian baru diperkirakan dapat menghindari antibodi yang disediakan oleh vaksin. Penelitian oleh Butt dan koleganya (2021) menemukan tidak banyak faktor yang terkait dengan breakthrough infection setelah vaksinasi. Tingkat breakthrough infection di antara orang-orang yang telah divaksinasi lengkap umumnya rendah tetapi tetap signifikan. Bertambahnya usia dan adanya komorbiditas meningkatkan risiko breakthrough infection. Oleh karenanya kampanye tentang kesadaran menerapkan protokol kesehatan, terutama yang ditargetkan kepada mereka yang berisiko diperlukan untuk mengurangi risiko.

Dengan besarnya populasi yang telah divaksinasi, maka banyak kasus breakthrough infection yang muncul ke permukaan. Selain faktor risiko yang disebutkan di atas, hasil studi yang dipublikasikan di timesofindia.com (2021) menunjukkan bahwa gaya hidup (lifestyle) juga merupakan salah satu faktor resiko yang harus diperhitungkan. Seseorang dengan gangguan penggunaan zat (SDUsubstance use disorder) yaitu ketika seseorang bergantung pada mariyuana, alkohol, kokain, opioid, dan tembakau, menjadi 8 persen lebih rentan terhadap breakthrough infection. Bagi mereka yang tidak memiliki kondisi tersebut, jumlahnya turun menjadi 3,6 persen. Jadi meskipun vaksin sangat efektif melawan COVID-19, efektivitasnya pada individu dengan SUD mungkin dibatasi oleh status kekebalan yang terkontaminasi. Risiko breakthrough infection pada individu dengan SUD 
meningkat dari 6,8 persen untuk perokok menjadi 7,8 persen untuk pengguna ganja. Sementara pada populasi non-SUD, hanya 3,6 persen. Data ini menunjukkan bahwa individu dengan SUD yang divaksinasi penuh berisiko lebih tinggi untuk mengalami breakthrough infection, dan ini sebagian besar disebabkan oleh prevalensi komorbiditas yang lebih tinggi dan determinan sosial ekonomi yang merugikan kesehatan dibandingkan dengan individu non-SUD.

\section{Tinjauan Pustaka}

Kondisi yang masih belum menentu selama pandemi dari awal tahun 2020 hingga saat ini, membawa konsekuensi pada sirkulasi informasi di dalam masyarakat juga penuh dengan dinamika. Informasi terus berubah dan berayun seperti pendulum dari yang bersifat negatif tentang ancaman dan risiko yang mengancam kehidupan, lalu beralih ke harapan yang tumbuh karena keberhasilan pengendalian pandemi dan perbaikan ekonomi. Karena serangan virus Covid-19 ini datang secara bergelombang yang disebabkan oleh munculnya berbagai varian baru, maka begitu pula valensi informasi yang menerpa masyarakat. Meskipun demikian peringatan akan ancaman virus yang masih terjadi dan anjuran untuk menerapkan protokol kesehatan, merupakan informasi publik yang disampaikan oleh banyak sumber melalui hampir seluruh saluran media dan secara konsisten tersirkulasi di tengah masyarakat. Informasi seperti ini dikenal sebagai health risk messages. Kim Witte dan koleganya $(2001,2)$ menjelaskan bahwa health risk messages merupakan pesan dengan fear appeals (membangkitkan rasa takut) yang paling banyak digunakan dalam domain kesehatan atau domain yang membawa risiko. Orang-orang secara alami akan merasa takut akan penyakit, cedera, dan kematian, serta ingin tetap sehat. Jadi, pesan kesehatan yang menyampaikan risiko adalah fear appeals. Yaitu pesan yang (umumnya bersifat persuasif) disampaikan untuk mempromosikan kesehatan dan pencegahan penyakit dengan menguraikan konsekuensi negatif yang terjadi jika tidak melakukan perlindungan tertentu. Informasi semacam ini membangkitkan rasa takut dengan mengatakan bahwa orang akan terluka, sakit, atau bahkan meninggal jika tidak melakukan apa yang disarankan oleh pesan tersebut. Jadi, sebagian besar pesan risiko kesehatan adalah fear appeals.

Kim Witte lebih lanjut mengembangkan extended parallel process model (EPPM) yang menjelaskan bagaimana orang mengelola rasa takut yang dihasilkan dari pesan tentang ancaman. Ketakutan adalah motivator utama perilaku kesehatan dan sering digunakan dalam pesan yang ditemukan dalam kampanye komunikasi untuk mendorong perilaku prososial dan sehat atau mencegah perilaku antisosial dan tidak sehat (Witte, 2001; Littlejohn, 2017). Misalnya, ada banyak informasi tentang kewajiban penggunaan masker di tempat umum dengan menginformasikan bahwa orang akan ditolak kehadirannya jika tidak menggunakan masker, atau bahwa tidak memakai masker akan menyebabkan kerugian yang signifikan bagi diri sendiri dan keluarganya jika orang tersebut terpapar virus Covid-19. Secara teoritis, ini adalah konsekuensi yang akan ditakuti oleh banyak orang. Ketakutan tersebut akan mempengaruhi orang memakai masker untuk menghindari konsekuensinya. EPPM mencoba menjelaskan bagaimana rasa takut dapat disalurkan untuk menghasilkan tindakan proaktif, sehat, dan melindungi diri dari mereka yang terpapar pesan tersebut.

Bagaimana orang mempersepsikan ancaman dan bagaimana informasi tentang ancaman tersebut dapat mempengaruhi sikap dan perilakunya dijelaskan oleh Information Integration Theory. Fokus dari teori ini adalah penjelasan mengenai cara kita mengumpulkan dan mengolah informasi tentang orang, objek, situasi, dan ide untuk membentuk sikap-predisposisi untuk bertindak dalam cara yang positif atau negatif terhadap sesuatu hal atau objek. 
Sikap dianggap sebagai akumulasi informasi tentang suatu objek, orang, situasi, atau pengalaman. Teori ini adalah salah satu model paling populer yang digunakan untuk menjelaskan bagaimana informasi membentuk sikap dan menghasilkan perubahan sikap (Littlejohn, 2017). Teori yang dikemukakan oleh Martin Fishbein ini menyatakan bahwa ketika kita memperoleh informasi baru (seringkali dari pesan persuasif), potongan informasi baru itu akan mempengaruhi sikap kita. Informasi baru tersebut belum tentu akan menggantikan sikap kita yang ada. Namun, ketika kita mempelajari informasi baru yang positif, sikap negatif cenderung menjadi kurang negatif dan sikap yang positif cenderung menjadi agak lebih positif. Jadi sikap dibentuk dan diubah melalui integrasi (pencampuran, penggabungan) informasi baru dengan kognisi atau pemikiran yang telah ada. Selanjutnya, teori ini menjelaskan bahwa setiap unit informasi memiliki dua kualitas penting, yaitu bobot dan nilai. Nilai dari informasi adalah evaluasinya (menguntungkan atau tidak), dan bobotnya adalah apakah informasi tersebut dianggap penting atau tidak. Informasi yang dianggap bernilai tinggi, sangat disukai (atau sangat tidak disukai), dan berbobot tinggi (sangat penting bagi kita) akan memiliki pengaruh yang lebih besar terhadap sikap kita daripada informasi yang bernilai atau berbobot rendah.

Pada sisi yang lain, Melvin Defleur berargumentasi bahwa ada tiga hal yang menentukan interpretasi orang terhadap informasi yang diperolehnya (2016, 136137). Pertama adalah konsep yang disebut "individual differences" pada latar belakang psikologis dan kognitif orang. Perbedaanperbedaan ini secara langsung terkait dengan minat, kebiasaan, preferensi, dan selera pribadi yang merupakan produk dari pengalaman belajar sebelumnya. Jadi, ketika orang memproses informasi apa pun, termasuk konten media massa, perbedaan individu akan menjadi faktor penentu bagaimana individu merespons informasi tersebut. Kedua, pada umumnya masyarakat modern dicirikan oleh sejumlah besar kategori sosial (social category) yang khas. Artinya, orang dapat diklasifikasikan dalam berbagai cara, berdasarkan agama, etnis, posisi pekerjaan, pencapaian pendidikan, identitas ras, kebangsaan asal, afiliasi politik, nilai ekonomi, dan sebagainya. Ketiga, ketika orang menghadapi masalah yang sama, memiliki minat yang sama, dan mengembangkan gaya hidup yang sama, maka anggota dari kategori tersebut, kemudian, mengembangkan pola pikir dan tindakan yang agak seragam saat mereka secara kolektif mengatasi lingkungan mereka, maka akan terbentuk pola-pola yang kemudian disebut subkultur. Karakteristik psikologis, sosial, dan budaya inilah yang diyakini membuat individu memiliki sejumlah keseragaman namun sekaligus sangat berbeda satu sama lain, dalam mempersepsikan dan menanggapi berbagai fitur lingkungannya-termasuk informasi dari media massa.

\section{Konseptualisasi Penelitian}

Studi ini mengukur korelasi antara beberapa variabel sosial demografis dan gaya hidup dengan persepsi tentang risiko terinfeksi Covid-19 di dalam lingkungan informasi yang disebut sebagai health risk messages. Informasi ini meliputi berbagai pesan yang mengingatkan tentang protokol kesehatan, berbagai kejadian aktual tentang kasus dan virus Covid-19, dan perkembangan harian tentang angka/statistik kasus Covid-19 yang disampaikan oleh berbagai media serta jaringan komunikasi antar pribadi. Variabel sosial demografis meliputi umur, jender, dan tingkat pendidikan, serta riwayat penyakit yang sedang atau pernah dimilikinya. Sedangkan variabel gaya hidup mencakup konsumsi rokok dan aktivitas di luar rumah yang potensial untuk terpapar Covid-19 seperti tuntutan pekerjaan dan bersosialisasi.

Penelitian dilakukan melalui metoda survei terhadap orang yang telah melakukan vaksinasi Covid-19, baik vaksinasi lengkap maupun vaksinasi pertama. Survei melalui 
kuesioner online yang dilakukan mulai akhir Agustus hingga 10 November 2021 berhasil mengumpulkan 295 tanggapan valid dari responden. Analisis data dilakukan dengan menggunakan uji korelasi, selain analisis deskriptif.

\section{Hasil Penelitian}

Responden dalam penelitian ini 61,4 persen adalah perempuan dan 38,6 persen laki-laki. Mereka berumur antara 18 tahun sampai dengan 57 tahun, dengan proporsi yang cukup besar pada kelompok umur 1921 tahun dan 28-35 tahun. Mereka berasal dari berbagai kota di Indonesia, dan proporsi yang cukup besar berasal dari kota Semarang, wilayah aglomerasi Jabodetabek, Magelang, Purworejo, dan Wonogiri. Kualifikasi pendidikan mereka adalah tamat SMA $(50,8 \%)$ dan tamat perguruan tinggi $(49,2 \%)$. Komposisi pekerjaan responden sebagian besar $(50,5 \%)$ adalah mahasiswa/mahasiswi pada berbagai jenjang, dan sisanya secara berurutan adalah karyawan swasta, tenaga kependidikan dan kesehatan, pekerja sektor publik, wiraswasta, mengurus rumah tangga, dan tidak bekerja. Sebesar 14,2 persen dari total responden memiliki riwayat penyakit dan kombinasi penyakit. Beberapa jenis penyakit yang dominan adalah hipertensi, asma, diabetes, dan lambung.
Sebagian besar responden tidak mengkonsumsi rokok, proporsi mereka yang mengkonsumsi rokok adalah 11,5 persen. Berkaitan dengan aktivitas di luar rumah yang tentu saja meningkatkan resiko di masa pandemi Covid-19, terlihat bahwa lebih banyak responden yang dapat melakukan pekerjaan dari rumah $(57,6 \%)$ dibanding sisanya $(42,4 \%)$ yang karena alasan pekerjaan harus melakukan aktivitasnya di luar rumah. Perilaku yang kurang kondusif justru terlihat dari kebiasaan responden untuk sering bersosialisasi di luar rumah. Proporsi responden yang sering bersosialisasi di luar rumah mencapai 50,8 persen. Bantuan teknologi komunikasi untuk bersosialisasi ternyata belum cukup kuat untuk mengurangi interaksi sosial langsung di luar rumah, yang meningkatkan resiko di masa pandemi. Data ini juga menunjukkan bahwa gaya hidup dapat menjadi pendorong yang lebih kuat untuk mengambil suatu risiko.

\section{Analisis dan Interpretasi}

Bagian penting dari studi ini adalah menakar persepsi terhadap risiko, yaitu persepsi responden tentang potensi mereka untuk terpapar Covid-19 meskipun mereka telah mendapatkan vaksinasi Covid-19. Dengan skala interval mulai dari 1 sampai dengan 5 untuk menunjukkan potensi keterpaparan Covid-19 (kemudian

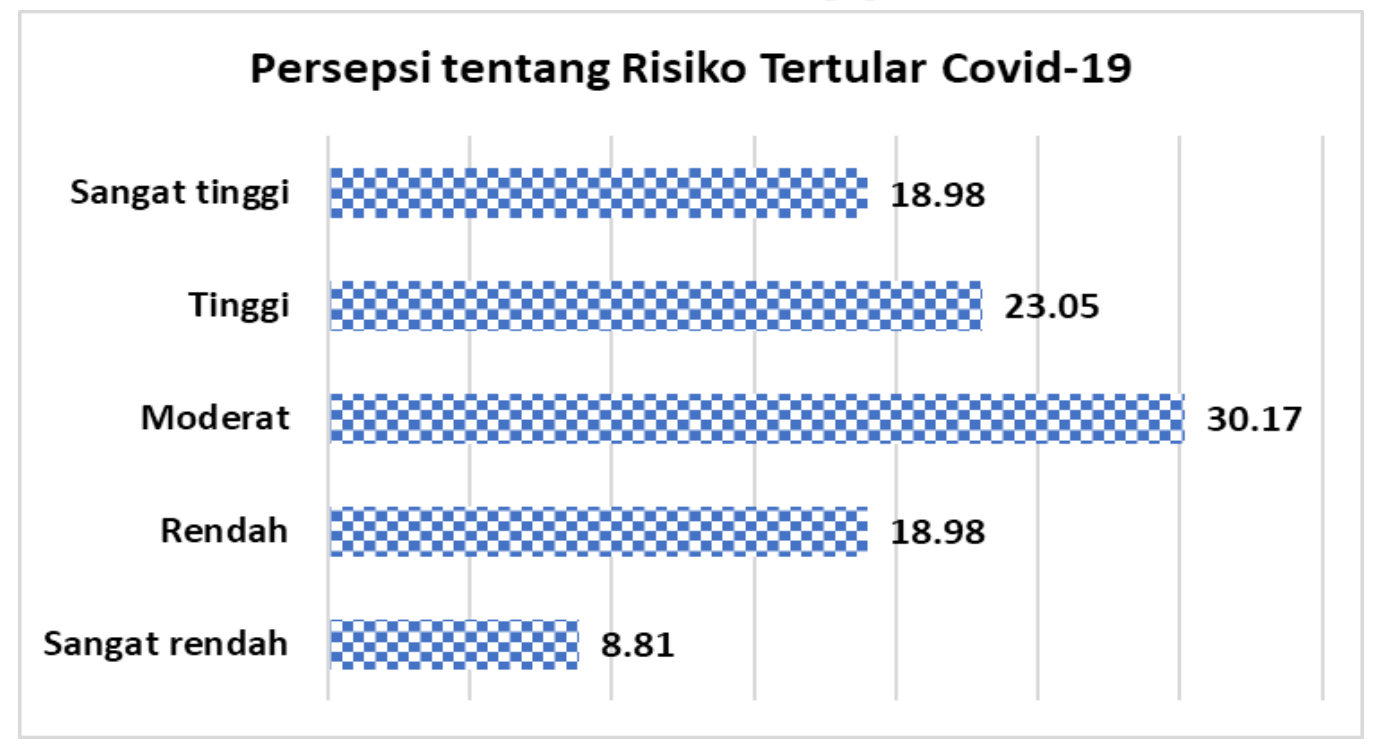

Gambar 1. Persepsi tentang Risiko Tertular Covid-19 
dikonversi menjadi sangat rendah hingga sangat tinggi), tanggapan responden menunjukkan bahwa masih lebih banyak responden (dengan menggabungkan kategori tinggi dan sangat tinggi) yang menganggap besarnya kemungkinan mereka untuk terpapar Covid-19 daripada mereka yang mempersepsikan sebaliknya. Kondisi ini tentunya baik, dalam pengertian bahwa mereka aware dan masih merasakan 'ancaman' dari risiko penularan Covid-19, dan pada gilirannya akan menumbuhkan sikap dan perilaku yang lebih berhati-hati agar tidak menanggung konsekuensinya.

Uji korelasi berganda Pearson terhadap hubungan antara karakteristik sosial demografis, seperti umur, jender, dan tingkat pendidikan dengan persepsi tentang risiko tertular Covid-19 menghasilkan tingkat signifikansi sebesar 0,422, yang mengindikasikan tidak adanya hubungan antara karakteristik sosial demografis dengan persepsi tentang risiko tertular Covid-19. Sementara uji korelasi berganda antara variabel-variabel yang menunjukkan adanya risiko yang lebih tinggi untuk terpapar Covid-19 yaitu memiliki riwayat penyakit dan variabel-variabel gaya hidup yang meliputi mengkonsumsi rokok, beraktivitas di luar rumah, dan bersosialisasi di luar rumah, dengan persepsi tentang risiko tertular Covid-19, menghasilkan tingkat signifikansi sebesar 0,006. Hasil uji ini menunjukkan adanya korelasi antara variabel kepemilikan riwayat penyakit, kebiasaan mengkonsumsi rokok, aktivitas pekerjaan di luar rumah, dan kebiasaan sosialisasi di luar rumah, dengan persepsi tentang risiko tertular Covid-19, dengan koefisien korelasi sebesar 0,219.

Pengujian berikutnya adalah mengukur korelasi jumlah risiko yang dimiliki dengan persepsi tentang risiko tertular Covid-19. Variabel jumlah risiko diperoleh dengan mengakumulasi riwayat penyakit, konsumsi rokok, beraktivitas di luar rumah, dan bersosialisasi di luar rumah. Hasil uji korelasi sederhana antara jumlah risiko yang dimiliki dengan persepsi tentang risiko tertular Covid-19 sangat signifikan pada alfa 0,000, dengan koefisien korelasi 0,213 . Jadi dapat dikatakan bahwa terdapat hubungan positif antara banyaknya risiko yang dimiliki dengan tingginya persepsi tentang risiko tertular Covid-19.

\section{Simpulan}

Analisis korelasi yang dilakukan menunjukkan adanya keragaman hasil pengujian. Sebagian mengkonfirmasi asumsi yang disusun sebagai landasan studi ini, dan sebagian lainnya tidak. Perbedaan individual yang didasarkan pada variabel sosial demografis tidak berkorelasi dengan persepsi tentang risiko tertular Covid-19. Sedangkan beberapa kategori sosial dan kultural, khususnya yang berkaitan dengan gaya hidup berkorelasi positif dengan persepsi tentang risiko tertular Covid-19. Bersamaan dengan variabel riwayat penyakit, variabel lain yang menjadi fokus dalam gaya hidup ini adalah yang dianggap memiliki risiko yang lebih besar untuk terpapar Covid-19 melalui transmisi virus antar individu dan gangguan terhadap imunitas tubuh. Poin terpenting yang perlu diperhatikan adalah adanya korelasi positif antara awareness pada jumlah risiko yang dimiliki oleh individu dengan persepsi tentang risiko tertular Covid-19. Data ini merupakan indikasi positif dalam konteks pencegahan terjadinya breakthrough infection karena individu yang menyadari bahwa kondisi dan perilakunya memiliki banyak risiko, akan mempersepsikan potensinya untuk tertular Covid-19 juga tinggi. Demikian juga sebaliknya. Persoalannya adalah ketika individu memiliki kesadaran tersebut, maka mereka harus berusaha untuk melindungi diri secara lebih serius dan konsisten.

\section{Referensi}

Defleur, M.L., 2016. Mass Communication Theories: Explaining Origins, Processes and Effects. New York, NY: Routledge. 
Littlejohn, S.W., Foss, K.A., Oetzl, J.G. 2017. Theories of Human Communication (11 $1^{\text {th }}$ edition). Long Grove, Illinois: Waveland Press, Inc.

Witte, K., Meyer, G., Martell, D.P. 2001. Effective Health Risk Messages: A stepby-step guide. Thousand Oaks, California: Sage

Butt, A.A., Khan, T., Yan, P., Shaikh, O.S., Omer, S.B., Mayra, F., 2021. Rate and risk factors for breakthrough SARS$\mathrm{CoV}-2$ infection after vaccination. $\mathrm{J}$ Infect. doi: 10.1016/j.jinf.2021.05.021 (PMCID: PMC8159711)

Maragakis, L., Kelen G.D. 2021. Breakthrough Infections: Coronavirus After Vaccination. https://www.hopkinsmedicine.org/healt h/conditions-anddiseases/coronavirus/breakthroughinfections-coronavirus-aftervaccination, di akses 30 November 2021.

Parker-Pope, T. 2021. Worried About Breakthrough Infections? Here's How to Navigate This Phase of the Pandemic. https://www.nytimes.com/article/break through-infections-covid-19coronavirus.html di akses 30 November 2021.

Coronavirus: Study finds a new risk factor for breakthrough COVID-19 infection, here's what it

is.https://timesofindia.indiatimes.com/1 ife-style/health-fitness/healthnews/coronavirus-study-finds-a-newrisk-factor-for-breakthrough-covid-19infection-heres-what-it- is/photostory/86963324.cms di akses 30 November 2021.

Kompas, 8 Desember 2021, halaman 1. 